\title{
The Importance of Moving to International Financial Reporting Standards for Indonesian Companies
}

\author{
By \\ Andian Ari Istiningrum ${ }^{1}$
}

\begin{abstract}
The aim of this study is to determine basic differences between US GAAP and IFRS and provides some solutions to overcome problems that arise due to those differences. Literature review is used in this study to obtain the data about the effects of moving to IFRS in other countries. The results that are achieved in this study are: (i) transition to IFRS will change financial position, financial performance, and cash flows of companies, (ii) benefits that companies take from transition to IFRS outweigh all costs that incur in the conversion, and (iii) IFRS 1 provides important guidance for a first time adopter.
\end{abstract}

Keywords: US GAAP, IFRS

\section{Introduction}

Globalization is still faced as an interesting issue that is still needed to be discussed. By globalization, there will be fewer barriers from one country to market their products to other countries, so it easy for people to consume products that can not be produced in their country and finally it may result in creating single market in this world. The effect of globalization also occurs in the world of capital market. The multinational companies may look for capital in other countries in order to expand their business. One way to seek capital in other countries is by listing their company in those countries' stock exchange. One requirement to be listed in the stock exchange is by submitting financial statement that is made based on the accounting standard used in the country where the stock exchange is located. This means that those companies have to make financial statement by using accounting local standard and they have to translate financial statement prepared based on their accounting standard to local accounting standard. The same problem also occurs in the case of holding company that has many subsidiaries in other countries. Subsidiaries have to prepare a financial statement using local accounting standard. They also have to translate the financial statement into accounting standard that is used by their parents. All of these processes take more effort, time and cost.

The use of different accounting standards also affects comparability of financial statements. It creates difficulties for investors and creditors to analyze and compare financial statement for multinational company, holding company and subsidiary company. The different standard may lead investors and creditors to interpret financial statement in their own way and it may result in a bad investment decision. For example, Daimler-Benz Company-one company in German- reports a net profit based on German Accounting Standard at 602 million DM in 1993. After its financial statement is translated into US Accounting Standard, it reports a loss at 1,839 million DM (Giri, 2008: 8).

\footnotetext{
${ }^{1}$ Dosen Jurusan Pendidikan Akuntansi - Universitas Negeri Yogyakarta
} 
Therefore, there is a need to use an international accounting standard that can unite all local accounting standards. The International Accounting Standard Committee (IASC) is an international accounting organization that has a primary duty to set international accounting standards. This organization was organized in 1973 and it has already produced 41 International Accounting Standards (IAS). The IASC then was replaced by The International Accounting Standard Board (IASB) in 2001. The IASB also has the same task as The IASC. The international standard set by IASB is known as International Financial Reporting Standards (IFRS). IASB has already set 7 IFRS to be used internationally by all companies.

According to Stovall (2010: 120), The IFRS has been implemented by 12.000 companies in more than 100 countries, including countries in the European Union, Hongkong, Australia, Russia, South Africa, Singapore and Pakistan. In addition, many countries have already implemented a plan to convert their financial statement into IFRS in the near future. This situation suggests that Indonesia should follow and adopt IFRS so that the business condition in Indonesia has a high opportunity to grow internationally.

The transition to IFRS may lead some problems. There are many people argue that the use of IFRS will lead some problems in increasing conversion costs. It may result in the significant loss for Indonesian Companies. However, The Indonesia Accountant Organization (IAI) has already announced that Indonesia will adopt IFRS in 2012. Therefore, a conversion plan should be made by all organization and institutions that are affected by this decision. The arguments that will be presented in this essay is that the benefits from moving to IFRS outweigh all of the costs that Indonesian Companies must pay. The topic will be addressed by discussing the differences between US GAAP and IFRS, benefits and costs of adopting IFRS, and what Indonesian Companies should do to prepare themselves in adopting IFRS

\section{Discussion}

\section{The Differences between US GAAP and IFRS}

Moving from US Generally Accepted Accounting Principles (US GAAP) to International Financial Reporting Standards (IFRS) will shift from rule-based approach to principle-based approach. IFRS offer less detail standards compare to US GAAP. There is a great flexibility for companies to prepare a financial statement that really appropriate with companies' transactions. Financial statement prepared using IFRS will be a mirror of the conditions faced by companies so it really reflects financial position and performance of companies. The same situation is more difficult to be achieved when companies use US GAAP. US GAAP is a very regulated standard that requests companies to follow all the procedures stated in the standards. Companies have fewer opportunities to select accounting procedures that suitable with their environment. Therefore, financial statement might not reflect the truth condition faced by companies.

The more principle-based approach in IFRS requires management to make professional judgment in selecting the most appropriate accounting procedures. According to Tomaszewsky and Jermakowicz (2010: 17-18) companies have greater flexibilities in choosing whether they will use cost or revaluation method in valuing property, plant and equipment, cost or fair value basis of accounting for investment property, proportionate consolidation or equity accounting of jointly entities, and finally fair value or proportionate share of the acquiree's identifiable net assets to measure non-controlling interest in consolidated financial statements. Selecting proper procedures needs the ability of 
management to understand the environments and the characteristics of their industries. Therefore, professional judgment is a primary key in implementing IFRS.

IFRS emphasizes on the use of fair value in valuing property and equipment, and financial instruments. On the other hand, US GAAP uses historical cost in measuring and valuing depreciable assets. In the revaluation approach, companies recognize depreciable assets at fair value less any accumulated depreciation and any impairment loss. Meanwhile, fair value is defined as exchange price of an asset between knowledgeable and willing parties in an arm's length transaction. It can be seen from this definition that market-based evidence by appraisal is considered important in determining fair value. However, if the nature of depreciable assets is very unique so there is no market for those assets, then it is permitted to use income or depreciated replacement cost method (Henderson, et al., 2008: 270). Under the revaluation method, the increase of fair value should be recorded as asset revaluation reserve which is a part of equity and the downward revaluation should be recognized directly as expense in the income statement. Stanko and Zeller (2010: 32) mentioned that the biggest challenge to asset revaluation is the subjectivity of the measurement. Their opinion seems rational since it is often not clear whether to value depreciable asset by using current net realizable value, current cost, present value of expected cash flow or other basis. The use of revaluation method will have a significant impact on the companies' financial position and companies' performance. For example, there will be a considerable change when unrealized gains should be recognized when companies decide to move to IFRS and use fair value measurement (Stovall, 2010: 125).

How to measure inventory based on IFRS is also different from US GAAP. IFRS prohibits the use of last in first out (LIFO) method; whereas US GAAP permits LIFO due to tax benefits the governments will get. Therefore, Indonesian Companies that already used LIFO should make adjustments to earnings, related ratios and tax consequences (Stanko and Zeller, 2010:32). No adjustments made means the companies will face tax liability. (Elena, et al., 2009: 280).

Another difference between US GAAP and IFRS is in the accounting for inventory write-down.US GAAP requires companies to apply the lower between cost or market to reduce value of inventory. Here, the market value means replacement value. Meanwhile, IFRS suggest that the lower between cost or net realizable value should be used in valuing inventory. The net realizable value is determined with an outlook of disposal. Moreover, US GAAP prohibits to reverse the write down to original value, but IFRS allows the reversal if business environment justify such an adjustment (Stanko and Zeller, 2010: 32).

The problem that arises because of the difference between US GAAP and IFRS also occurs in the field of accounting for leases. The main issue that always occurs in leasing area is whether to classify the lease as operating lease (the lease is recognized as an expense) or finance lease (the lease is capitalized and shown as an asset in the balance sheet). IFRS provides some criteria to classify the lease as finance lease:

1. The lease transfers ownership of the assets to the lessee by the end of the lease term.

2. Lessee has an option to purchase the assets at an expected price much lower than fair value at exercise date of option making it reasonably certain, at the beginning of the lease, that the option will be exercised.

3. The lease term is for the major part of the economic life of the asset even if ownership is not transferred. 
4. At the inception of the lease the present value of minimum lease payments amount to at least substantially all of the fair value of the leased asset.

5. The lease assets are such of a specialized nature that only the lessee can use the without major modification.

The above criteria do not provide a clear threshold to make a precise classification. Firstly, there is no clear guidance about the major part of economic life. Secondly, there is no obvious regulation for how much the minimal proportion of the present value of minimum payment should be. Therefore, professional judgment is really needed to classify leased asset. In addition, auditors also face difficulties to evaluate the accuracy of classification due to unclear standard. On the other hand, US GAAP specifies clearly that the lease contract term constitutes $75 \%$ or more of the useful life of the leased asset and the present value of the minimum lease payments is $90 \%$ or more of the fair value of the leased asset

Stanko and Zeller (2010: 32) mentioned that there is a significant difference in the measurement of contingent liabilities.US GAAP regulates companies to recognize contingent liabilities at the low end of the range of cost related with settling the obligation. IFRS does not apply this criteria. IFRS focuses on the use of mid range of the range and it causes higher contingent liabilities that are recorded in the balance sheet.

The last difference according to Stanko and Zeller (2010: 31) is located on the presentation of financial statement.US GAAP requires companies to present their assets based on the assets' liquidity, so the assets can be classified as current assets or non current assets. By contrast, IFRS do not state that assets should be presented in an order of liquidity. The same condition also occurs in the case of liabilities. US GAAP asks that presentation of liabilities is based on the age of the liabilities. All liabilities that have to be paid within one year are classified as short term liabilities and the obligations that will mature more than one year are classified as long term liabilities. Again, IFRS do not mention the specific rule to present liabilities.

\section{Benefits and Costs of Moving to IFRS}

Stovall (2010: 120) mentioned that there are several benefits received by using international accounting standard. The first benefit is that financial statement of one company can be compared internationally. The use of single accounting standard may help investors and creditors in analyzing financial statement of the company. It can be easier for them to compare the performance of the company with other companies in other countries since every company uses the same standard. Indonesian companies also take this benefit since the use of IFRS makes the Indonesian companies' financial statement more comparable and it creates more investment in Indonesia. On the other hand, Elena et al., (2009: 276) argued that the international comparability of financial statements is still difficult to be achieved although all the companies use IFRS. This happens due to the principle-based of IFRS that could be applied differently by companies.

The second benefit is that the access to international capital increases. Globalization leads every company to compete internationally by listing themselves in international capital market. By so doing, the companies can raise capital easily and expand their business globally (Stovall, 2010: 121). This will be a simple process if every company in the world practices the same accounting standard because the companies will not need to convert their financial statement to fulfill the requirements of the country in which the capital market was located. Elena et al.(2009: 276) supported this opinion. They stated that it is necessary for the investors to help them to make decisions by analyzing financial statements in the same 
interpretations. The same benefits are also expected by Indonesian Companies. It is necessary for Indonesia to use international standard because it will open an opportunity for multinational companies to have subsidiaries in Indonesia. The subsidiaries can easily become a branch of the holding companies without thinking about how to convert their financial statement into Indonesia accounting standard.

The third benefit is reducing conversions of financial statements between international companies. There is no need to convert financial statement to other standards if every company implement single standard and it may result in cutting cost significantly. According to Duverne cited in Stovall (2010: 121), AXA Company could reduce about \$25 million if its financial statement was not converted into US GAAP standard.

Then the last benefit is increasing disclosures so high quality of financial statement can be achieved. IFRS No 1 requires every company to disclose all the changes that occur because of the transition from local accounting standard to IFRS. By adding more information in the note, the quality of information presented in the financial statement will increase and the stakeholders will have knowledge of the effect of this transition.

Even though the transition to IFRS has many benefits, it seems that the cost needed to conform all requirements in the transition process also increase significantly. The conversion cost is predicted to increase up to $1 \%$ of revenue (Tomaszewski and Showerman, 2010: 63).To be able to prepare financial statement using the new standard requires employees that have knowledge about IFRS. It is important to the companies to train their employees in order to get this knowledge. In addition, problem also occurs in the internal control system. Managements need to reassess its system to know whether the system is influenced by the transition (Stovall, 2010). There is a high possibility that the internal control system should be adjusted so control over financial reporting is sufficient to prevent errors and irregularities that occur from the transition process. Information system is also affected by the conversion because there will be multiple charts of accounts and consolidation method that need to be synchronized with each other (Tomaszewski and Showerman, 2010: 63). The problem not only occurs in the process of preparing financial statement but also auditing financial statement. The auditors need more effort and time to examine financial statement prepared by using new standard so that they can provide correct opinion. All of these problems may result in increasing costs significantly.

Evaluating between the benefits it gets and the cost it pays is an important way to make a decision whether IFRS should be implemented in Indonesia. The decision maker should look at long term objective rather than short term. In the short term, many companies may suffer a significant loss as a result of increasing conversion cost. However, this situation may turn around in the long term. The benefits will outweigh the costs due to the possibility of Indonesian Companies to compete globally and increasing investment opportunity in Indonesia. The final result that wants to be achieved is better business and economic conditions in Indonesia.

\section{What Indonesian Companies Should Do}

In the transition phase, it is better for Indonesian companies to follow the guideline that is regulated by IFRS 1. IFRS 1 provides specific guidance for the first time adoption. Under IFRS 1, a first time adopter must present its financial statement in accordance with IFRS at least one year before the transition date. A first time adopter also need to recognize 
all adjustments in retained earnings and disclose the impact of moving to IFRS on its financial position, financial performance and cash flow in the note of financial statement (Tomaszewski and Jermakowicz, 2010: 14).

In addition, IFRS 1 also specify the steps that should be followed by a first time adopter in the hope that the transition process will run smoothly. The steps are:

1. Selecting accounting policies that are permitted under IFRS.

2. Preparing a financial statement that is appropriate with IFRS at least one year prior to the transition date. In this step, an accountant must do some works, such as:

(i) Review the company's financial statement and summary of significant accounting policies. Prepare a list of accounting areas for which sufficient information has been provided to determine that conversion is required. Include differences in presentation as well as accounting methods. For each item, list any additional information the accountant will need to obtain to complete the conversion.

(ii) Prepare a list of accounting areas for which adjustment may be necessary, but insufficient information was provided to make an accurate assessment. List the specific information the accountant will need in order to conduct advance analysis.

(iii)Use the additional information the accountant gathered to prepare a list of journal entries converting the company's US GAAP financial statement to IFRS.

(iv)Record the conversion entries and make any necessary changes to present the company's balance sheet and income statement in accordance with IFRS for the year before the transition date (Fay, et al., 2011: 1 - 2).

3. Presenting and disclosing the effects of transition to IFRS.

Another solution to be successful in the conversion to IFRS is offered by Elena,et al. (2009: 286). First, a company has to set a transition team. This team has a primary task to make a good preparation and implementation of moving to IFRS. Second, the team determines all the effects that occur due to the transition process and assesses the level of the risks that is appropriate with these effects. Third, the team develops the new system that is required by IFRS. Fourth, the team begins to build a good communication with management and implement the IFRS. Finally, the team and management work together to review the implementation of IFRS.

\section{Conclusion}

The use of local accounting standards is considered as bring some problems to Indonesian companies and investors. Both of them have to learn, implement and analyze two standards simultaneously. Therefore, it is necessary to move into an international standard. By moving to IFRS, it is expected that there will be an increase in the comparability of financial statement internationally, a rise in the access to international capital, a decrease in the conversion of financial statement among international companies, and an increase of higher quality of financial statement. The transition to IFRS also provides many challenges for Indonesian companies since there will be significant difference between US GAAP and IFRS. This means that Indonesian companies must make adjustments in certain areas that are affected by the transition to IFRS. To overcome all the obstacles that occur in the transition process, Indonesian companies may use IFRS 1 that provides important guidance for a first time adopter. 


\section{References}

Elena, Hlaciuc., Catalina, Mihalciuc., Stefana, Cibotariu and Niculina, Apetri, 2009, Some Issues about The Transition from US Generally Accepted Accounting Principles (GAAP) to International Financial Reporting Standards (IFRS), Annales Universitatis Apulensis Series Oeconomica, No. 11, pp. 275-289.

Fay, Rebecca.,Brozovsky, John A.,Lobingier, Patricia G, 2011, Ruckman,Inc.: Converting from US GAAP to IFRS. Issues in Accounting Education, No. 2, pp.41-360.

Giri, Efraim Ferdinan, 2008, Konvergensi Standar Akuntansi dan Dampaknya terhadap Pengembangan Kurikulum dan Proses Pembelajaran Akuntansi di Perguruan Tinggi Indonesia, Jurnal Pendidikan Akuntansi Indonesia, No. 2, pp. 7-19.

Henderson, Scott., Peirson, Graham and Herbohn, Kathy. 2008. Issues in Financial Accounting. New South Wales: Pearson Education Australia.

Stanko, Brian B and Zeller, Thomas L, 2010, The Arrival of A New GAAP: International Financial Reporting Standards, Journal of Business and Economic Research, No. 10, pp. 27 37.

Stovall, Dennis C., 2010, Transition to IFRS: What Can We Learn?, The Business Review, No.1, pp. 120-126.

Tomaszewski, Silvia G., and Jermakowicz, Eva K., 2010, Adopting IFRS: Guidance for US Entities under IFRS 1, The CPA Journal, No. 3, pp. 13-18.

Tomaszewski, Silvia G., and Showerman, Steve., 2010, IFRS in the United States: Challenges and Opportunities, Review of Business, No. 2, pp. 59-71 